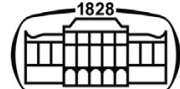

AKADÉMIAI KIADÓ

Acta Veterinaria

Hungarica

69 (2021) 4, 363-371

DOI:

$10.1556 / 004.2021 .00043$

(c) 2021 The Author(s)

\title{
Reproductive toxicological changes in avian embryos due to a pesticide and an environmental contaminant
}

\author{
JÓZSEF LEHEL ${ }^{1 *} \oplus$, GÉZA SZEMERÉDY ${ }^{2}$, RITA SZABÓ ${ }^{2}$, \\ LÁSZLÓ MAJOR ${ }^{2}$, ADRIENN GRÚZ ${ }^{2}$ and PÉTER BUDAI ${ }^{2 * *} \odot$ \\ ${ }^{1}$ Department of Food Hygiene, University of Veterinary Medicine, István u. 2, H-1078, Budapest, \\ Hungary \\ ${ }^{2}$ Institute of Plant Protection, Hungarian University of Agriculture and Life Sciences, Georgikon \\ Campus, Deák F. u. 16, H-8360, Keszthely, Hungary
}

Received: 9 July 2021 • Accepted: 27 September 2021

Published online: 8 November 2021

\section{RESEARCH ARTICLE}

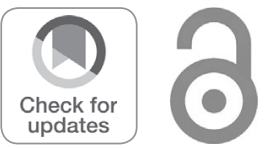

*Corresponding author. Tel.: $+36-1$ 478-4155.

E-mail: lehel.jozsef@univet.hu

** Corresponding author. Tel.: +36 83-545-226.

E-mail: budai.peter@uni-mate.hu

\section{ABSTRACT}

Single and simultaneous toxic effects of glyphosate (Amega Up, $360 \mathrm{~g} \mathrm{~L}^{-1}$, 4\%) and copper sulphate $(0.01 \%)$ were studied in avian embryos treated either with injection directly into the air chamber or by immersion application for $30 \mathrm{~min}$ on day 0 of incubation. Alterations of the chicken embryos were evaluated during necropsy performed on day 19 of incubation, together with mortality, body weight and the type of developmental abnormalities. Based on the results, the injection application appeared to be more toxic than the immersion method, as it induced increased mortality and reduced the average body weight, and resulted in a higher incidence of congenital anomalies. Supposedly, a toxicodynamic interaction occurs between copper sulphate and glyphosate, which may reduce the vitality of embryos and thus decrease the number of offspring in wild birds.

\section{KEYWORDS}

chicken embryo, immersion, injection, copper sulphate, teratogenicity, glyphosate

\section{INTRODUCTION}

Pesticides are used in agriculture mainly to control pests, fungi, and weeds. Their application in agriculture helps to increase the yield, improve the quality as well as extend the storage life of food crops. As plant protection products are biologically active, they have the potential to affect non-target organisms, particularly in terrestrial environments where exposure may be continuous. The excessive use of pesticides may lead to the destruction of biodiversity. Many birds, aquatic organisms and animals are under the threat of harmful pesticides for their survival (Mahmood et al., 2016).

Besides adult birds, embryos in the eggs are threatened, because these chemicals can penetrate the porous eggshell and increase the mortality or development anomalies of embryos as well (Kertész, 2001).

An ecosystem can be contaminated by pesticides sprayed alone or applied together with other xenobiotics (e. g. potentially hazardous elements). Different pesticides can be used together as a mixture at the same time, can be applied alone step by step, one after the other, or metals may be present naturally in high amounts in a given area. Glyphosate and glyphosate-based herbicides are among the most frequently applied pesticidal active substances/pesticide products, while copper with fungicidal action is sprayed extensively for different purposes. Thus, the chemical load can generally appear in a complex way, therefore the simultaneous toxic effect and interaction of chemical agents can be expected at the same time. 
Over the past 30 years, there has been a significant increase in the number of studies on the effects of pesticides including their accumulation and their impact on wildlife. In the 1960s and 1970s a dramatic decline occurred in wildlife populations due to the use of pesticides based on organochlorine compounds, which could be traced back to the death of birds of prey (Köhler and Triebskorn, 2013). The components can modify each other's toxic effect. Therefore, the examination of the combination of potentially hazardous elements and other chemicals gained significant ground in both avian (Fejes et al., 2001; Kertész and Hlubik 2002) and mammalian (Institóris et al., 2001; Pecze et al., 2001) toxicological research studies. Furthermore, the interaction effects are studied not only in the field of ecotoxicology, but also in all other areas dealing with healthcare and chemical safety issues (Oskarsson, 1983; Danielsson et al., 1984; Speijers and Speijers, 2004).

Copper has been used in agriculture due to its fungicidal and bactericidal properties for over a century (La Torre et al., 2018). It is essential in trace amounts for the normal development of living organisms, as it is a cofactor in many enzymes responsible for important processes in cells. On the other hand, it can trigger the production of free radicals, which can damage proteins and DNA (Ogórek et al., 2017). Copper is strongly bioaccumulative. Biological activity is a major factor in determining the occurrence and distribution of copper in an ecosystem (Aaseth and Norseth, 1986; Hejnal et al., 2018). It can be found in agricultural soils, in varying degrees originating from agrarian sources, e.g. manure, sewage sludge, fertilisers, and pesticides (Mantovi, 2003). Copper is important in integrated pest management. In organic farming it is almost exclusively used to control many bacterial and fungal diseases. However, the long-term consequences of its accumulation in the soil should be considered (La Torre et al., 2018) since it can be transferred easily to animals and humans as well through the food chain. Quantities exceeding the essential amount can be toxic, but sensitivity to copper toxicosis is species dependent. Generally, poultry resist chronic toxicosis better than most mammals (NRC, 1977). The contamination of agricultural soil with copper is a concern for the state of our environment and food safety (Komárek et al., 2010).

Glyphosate came on the market in the 1970s, to become one of the most often used herbicidal active ingredients in the world at present. It is a broad-spectrum herbicide, used in weed control in agriculture, and vegetation control in non-agricultural areas (Solomon et al., 2007.) Thus, based on its widespread use, glyphosate may have negative effects on animal and human health due to its possible residues in feeds and foods (Cox, 1995; Krüger et al., 2014; Blaylock, 2015; Faria, 2015). It disrupts the Shikimate pathway of plants and some microorganisms by inhibiting the enzyme EPSP (5-enolpyruvylshikimate-3phosphate) synthase (Lipok et al., 2010). This process reduces the biosynthesis of aromatic amino acids (tyrosine, tryptophan, phenylalanine) in target organisms, resulting in their death (Nielsen et al., 2018). This pathway is not found in animal cells and, thus, glyphosate is considered relatively non-toxic to animals and is also environmentally safe (Giesy et al., 2000; Duke et al., 2012; Helander et al., 2012; Annett et al., 2014).

A teratological test performed on avian embryos is quick and accurate and allows investigation of the chemical impact on fetal development. Further advantages of this method include its low cost, its sensitivity to various agents, as well as its high degree of similarity to the morphological development of mammals (Korhonen et al., 1982). The major disadvantage of this type of study is the lack of maternalfetal relationship and the high sensitivity of the embryo (Wilson, 1978).

Different application methods are recommended to investigate the toxic effects of chemical agents on the egg and the avian embryo (Hoffman and Gay, 1981). The most frequently used administration is the injection of the test substance into different parts of the egg, e. g. into the air chamber. Its advantages are that physical injuries of the embryo can be avoided during the application, the exact dose can be applied and thus the teratogenic alterations caused by the given concentration can be precisely calculated, and the results of the study can be properly evaluated (Meiniel, 1977; Várnagy et al., 1982). However, the injection method does not reflect field exposure, and the residues of the chemicals cannot appear at the same stage of embryonic development as after immersion treatment (Varga et al., 2002). However, in the case of the immersion method the amount of chemicals entering the egg cannot be exactly calculated because their penetration can be influenced by the permeability of the eggshell that is characteristic to a given species, as well as by different environmental factors (Tyler, 1955; Tullett and Deeming, 1982).

Teratological tests carried out on avian embryos provide useful data for environmental protection and for the protection of wild birds and their progeny, and facilitate the development of environmental-friendly chemical plant protection techniques (Várnagy et al., 1996).

The current study was designed to examine the individual and combined embryotoxic effects of potentially hazardous elements such as heavy metal (copper) modelling the heavy metal load of the environment and a glyphosatebased herbicide formulation (Amega Up, glyphosate isopropylamine salt) widely applied in the practice, on the development of chicken embryos.

\section{MATERIALS AND METHODS}

\section{Test system}

Three hundred and twenty, mixed-use Farm hen eggs (Goldavis Ltd., Hungary) with good fertility were used in the experiment (Table 1). They were randomised into eight groups (40 eggs/group) based on their size and weight. The eggs were incubated in a Ragus type table incubator (Vienna, Austria), applying adequate temperature $\left(37-38^{\circ} \mathrm{C}\right)$, relative humidity (65-70\%) and daily rotation of the eggs during the incubation. 
Table 1. Experimental design

\begin{tabular}{lccc}
\hline & & \multicolumn{2}{c}{ Treatment } \\
\cline { 3 - 4 } Group & No. of eggs & $\begin{array}{c}\text { Copper } \\
\text { sulphate }\end{array}$ & $\begin{array}{c}\text { Glyphosate } \\
\text { (Amega Up) }\end{array}$ \\
\hline Injection method & & & \\
I (control) & 40 & - & - \\
II & 40 & $0.01 \%$ & - \\
III & 40 & - & $4 \%$ \\
IV & 40 & $0.01 \%$ & $4 \%$ \\
Immersion method & & & - \\
V (control) & 40 & - & - \\
VI & 40 & $0.01 \%$ & $4 \%$ \\
VII & 40 & - & $4 \%$ \\
VIII & 40 & $0.01 \%$ & \\
\hline
\end{tabular}

\section{Test substances}

During the injection and immersion treatment, copper sulphate (Reanal-Ker Ltd., Budapest) was applied in a concentration of $0.01 \%$ using the results of a previous study (Fejes, 2005). The glyphosate-containing herbicide (Amega $\mathrm{Up}$, glyphosate isopropylamine salt, $360 \mathrm{~g} \mathrm{~L}^{-1}$, Nufarm Hungary Ltd.) was administered as a $4 \%$ emulsion corresponding to that used in plant protection practice. The test substances were used by individual and simultaneous application in these concentrations.

Avian physiological saline solution $(0.75 \%$ sodium chloride) was used to dilute the test substances and for the treatment of the control eggs. The experimental design is presented in Table 1.

\section{Treatments}

The study and the treatments were performed in accordance with the methods described by Várnagy et al. (1981). All applicable international, national and/or institutional guidelines for the care and use of animals were followed. The experimental protocol of the study was approved by the local Committee of Animal Welfare at Pannon University, Georgikon Faculty (permission No.: MÁB-10/2019).

Injection method. The individually and/or simultaneously applied test substances and the saline solution were administered in a volume of $0.1 \mathrm{ml}$ directly into the air chamber of the eggs with a micropipette on day 0 of incubation, depending on the treatment groups. Initially, the blunt ends of the eggs were disinfected with $70 \%$ ethanol, then the calciferous eggshell was drilled through (Forte 300 dental drill, Netdent Trade Ltd., Hungary) before the injection, and the hole was closed with paraffin after the treatment (Clegg, 1964).

Immersion method. For the immersion method, chicken eggs were dipped into the solution or emulsion of the test substances and/or saline solution for $30 \mathrm{~min}$ on day 0 of incubation at room temperature (Várnagy et al., 2000). The applied concentration of the test substances was the same as for the injection method.

\section{Investigated parameters}

The eggs and the embryos were processed by necropsy on day 19 of incubation, and the following parameters were monitored for evaluation: mortality, body weight, and developmental abnormalities of the embryo. Skeletal preparations of the embryos were made using alizarin red dye to stain the bones and cartilages and to detect any possible developmental changes in the skeletal system, followed by stereomicroscopic evaluation (Dawson, 1926).

\section{Statistical analysis}

Statistical analysis of the body weight of live embryos was performed by one-way analysis of variance. The homogeneity of variances was examined by the Shapiro-Wilk test. Comparative evaluation of the results of different groups was carried out by Tukey's test. The mortalities and the developmental abnormalities of embryos were analysed statistically using Fisher's exact test. Statistical analysis of the data was performed using R statistical software.

\section{RESULTS}

\section{Injection method}

Embryonic mortality. The results of embryonic mortality are presented in Table 2 . The mortality rate was $7.5 \%$ in the control group. The single administration of copper sulphate increased the mortality up to $20 \%$ in Group II. The changes were not significantly different as compared to the control. Glyphosate caused an increase in mortality (35\%) in Group III, which was statistically significant as compared to the control $(P<0.05)$. Due to the simultaneous administration (Group IV), a significant increase in embryonic mortality (up to 40\%) was induced as compared to the control group $(P<0.001)$.

Developmental abnormalities. The rate of developmental abnormalities was $2.7 \%$ in Group I (Table 2). The single injection of copper sulphate induced leg deformation and open abdomen in a rate of 3.1\% (Group II), which was not significantly different from the control group. Similarly, a

Table 2. Mortality and developmental anomalies of embryos due to single and combined treatment by injection method

\begin{tabular}{|c|c|c|c|}
\hline Group & Treatment & $\begin{array}{c}\text { No. of embryos } \\
\text { showing } \\
\text { abnormality/No. of } \\
\text { live embryos }\end{array}$ & $\begin{array}{c}\text { No. of } \\
\text { deaths/Total } \\
\text { eggs }\end{array}$ \\
\hline I & Control & $1 / 37$ & $3 / 40$ \\
\hline II & Copper sulphate & $1 / 32$ & $8 / 40$ \\
\hline III & Glyphosate & $1 / 26$ & $14 / 40^{\mathrm{a}}$ \\
\hline IV & $\begin{array}{c}\text { Copper sulphate } \\
+ \text { Glyphosate }\end{array}$ & $3 / 24$ & $16 / 40^{\mathrm{b}}$ \\
\hline
\end{tabular}

a significant decrease compared to the control data $(P<0.05)$;

b significant decrease compared to the control data $(P<0.001)$. 

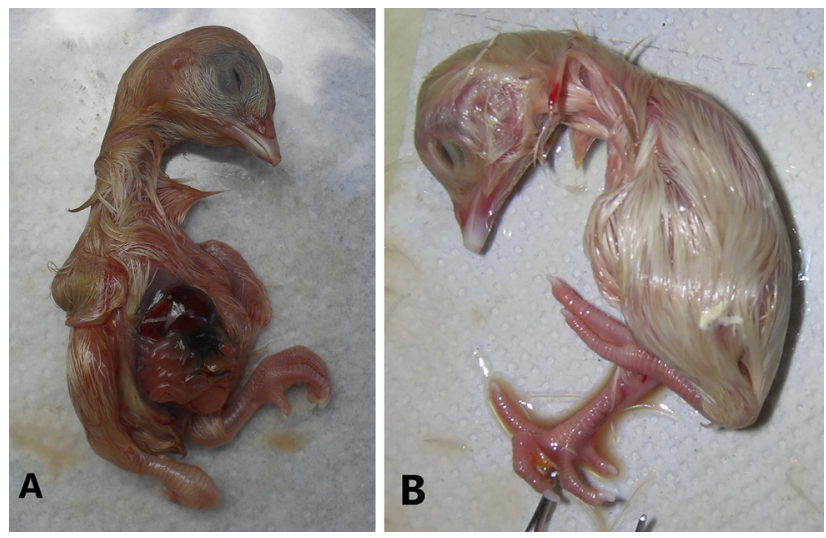

Fig. 1. Abnormalities: open abdomen (A) and leg deformation (B) caused by the simultaneous administration of copper sulphate and glyphosate

low malformation rate was observed in Group III. However, the simultaneous administration of copper sulphate and glyphosate (Group IV) caused an increase in the rate of developmental anomalies up to $12.5 \%$, including open abdomen and leg deformation (Fig. 1).

Body weight. The average body weight of the embryos was $20.87 \pm 1.61 \mathrm{~g}$ in Group II, which was significantly lower than in the control group $(21.96 \pm 1.16 \mathrm{~g}, P<0.05)$. Glyphosate treatment (Group III) did not cause a statistically significant change in the body weight $(21.04 \pm 1.92 \mathrm{~g})$. The simultaneous administration of copper sulphate and glyphosate resulted in a significant reduction $(P<0.001)$ of the average body weight (Group IV: $20.16 \pm 1.96 \mathrm{~g}$ ) as compared to the control (Fig. 2A).

Skeletal staining preparation. The highest rate of developmental disorders of the skeletal system (leg deformation, growth retardation; Fig. 3) were caused by the simultaneous use of copper sulphate and glyphosate; however, the anomalies were sporadic if the test substances were applied individually (Table 2).

\section{Immersion method}

Embryonic mortality. The results of embryonic mortality are presented in Table 3 . The percentage of dead embryos was $5 \%$ in the control group. The single administration of copper sulphate increased the mortality up to $7.5 \%$ in Group VI. The changes were not significantly different from those in the control group (Group V). Application of glyphosate caused $10 \%$ mortality of the treated embryos in Group VII, which was also not significantly different from that found in the control. The simultaneous administration of copper sulphate and glyphosate (Group VIII) induced a statistically not significant increase in embryonic mortality (12.5\%).

Developmental abnormalities. Developmental abnormalities were not recorded in the control group (Table 3). Single treatment with copper sulphate induced a $2.7 \%$ rate of
A

\section{INJECTION}

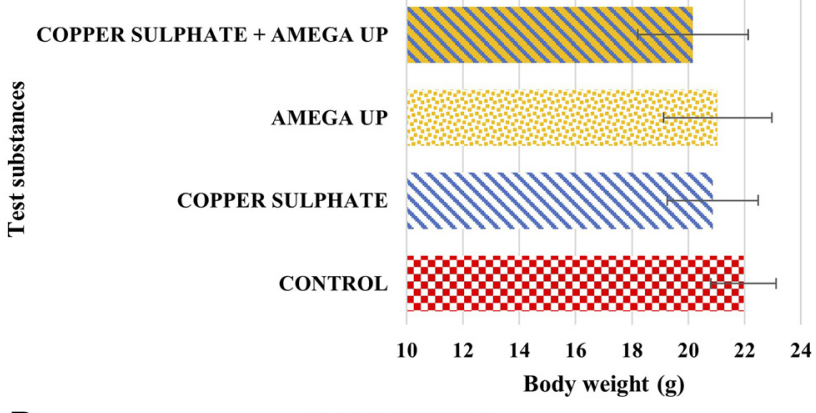

B

IMMERSION

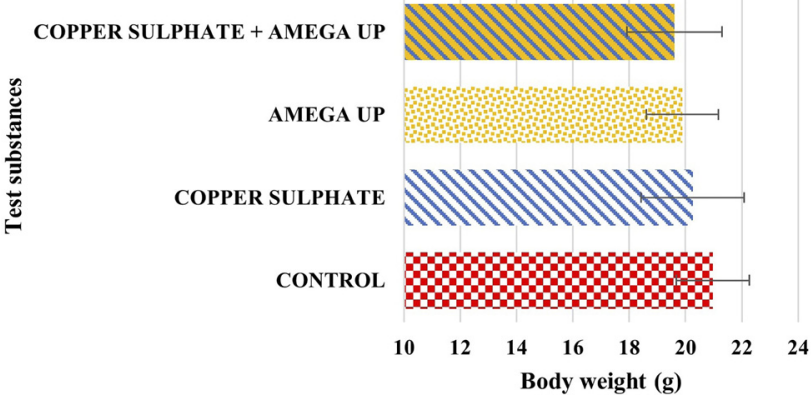

Fig. 2. Body weight (average $\pm \mathrm{SD}$; g) of the embryos after single and simultaneous administration of glyphosate and copper sulphate by injection method (Fig. 2A) and by immersion method (Fig. 2B). ${ }^{a}$ significant decrease as compared to the control data $(P<0.05) ;{ }^{b}$ significant decrease as compared to the control data $(P<0.001)$

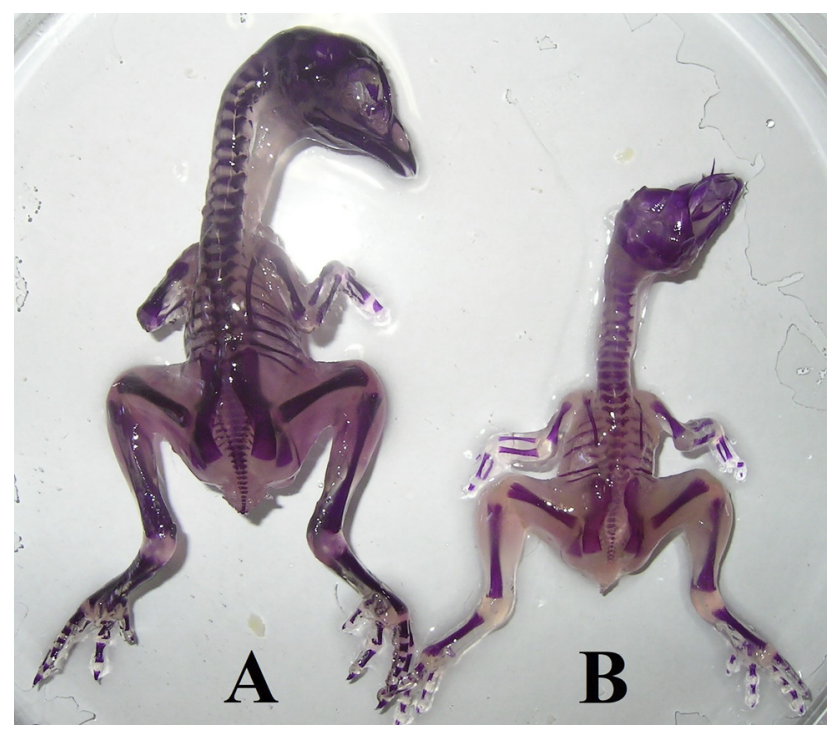

Fig. 3. Skeletal staining preparation. Normal development of control embryo (A) and growth retardation of an embryo (B) caused by the simultaneous use of copper sulphate and glyphosate

anomalies including leg deformation and open abdomen (Group VI), which was not significantly different as compared to the control group. The percentage of teratogenic malformations was $2.8 \%$ in Group VII due to the application of glyphosate. A similar rate of developmental abnormalities was found in Group VIII (2.9\%) due to the 
Table 3. Mortality and developmental anomalies of embryos due to single and combined treatment by immersion method

\begin{tabular}{lccc}
\hline Group & Treatment & $\begin{array}{c}\text { No. of embryos } \\
\text { showing } \\
\text { abnormality/No. of } \\
\text { live embryos }\end{array}$ & $\begin{array}{c}\text { Number of } \\
\text { deaths/Total } \\
\text { eggs }\end{array}$ \\
\hline V & Control & $0 / 38$ & $2 / 40$ \\
VI & Copper & $1 / 37$ & $3 / 40$ \\
VII & sulphate & & \\
VIII & Glyphosate & $1 / 36$ & $4 / 40$ \\
& Copper & $1 / 35$ & $5 / 40$ \\
& sulphate + & & \\
\hline
\end{tabular}

simultaneous administration of copper sulphate and glyphosate. Generally, leg deformations and growth retardation were induced by the glyphosate-containing herbicide applied alone or in combination (Group VIII). The rate of developmental anomalies was similar in all groups treated with the investigated chemicals.

Body weight. The average body weight of the embryos was $20.26 \pm 1.83 \mathrm{~g}$ in Group VI. It was not significantly reduced compared to the control group $(20.97 \pm 1.29 \mathrm{~g})$. Due to the glyphosate treatment (Group VII) the body weight was 19.89 $\pm 1.28 \mathrm{~g}$, which was significantly lower than in the control group $(P<0.05)$. The simultaneous administration of copper sulphate $(0.01 \%)$ and glyphosate (Group VIII) resulted in a significant decrease $(P<0.001)$ of the average body weight $(19.61 \pm 1.68 \mathrm{~g})$ compared to the control group (Fig. $2 \mathrm{~B})$.

Skeletal staining preparation. The skeletal development disorders (incorrect posture of the feet) induced by the individual or simultaneous application of the test substances were sporadic (Table 3).

\section{DISCUSSION}

Agricultural areas provide feedstuffs, living and hatching territory for wild birds, and thus the study of the environmental effect of different chemical agents including pesticides is very important. Depending on the exposure level they can induce acute damage or even destruction of living organisms.

The results of individual teratogenicity studies on copper sulphate in chickens are in accordance with those of toxicity studies in other species. Depending on its dose, copper has embryotoxic potential and may cause developmental anomalies (Várnagy and Budai, 1995).

According to our findings during the evaluation on day 19 , copper sulphate significantly increased the mortality rate and decreased the body mass of the embryos compared to the control group. These results are similar to those obtained in the experiment performed by Fejes (2005), where the eggs were treated by the injection of copper sulphate into the air chamber on days 1 and 12 of incubation.
In the injection groups, adverse effects were more pronounced and the rates of mortality and developmental anomalies were higher than in the immersion groups. This is in line with the findings of a study conducted on chicken embryos by Kertész (2001), indicating a slower onset of toxicity because the compounds must penetrate the eggshell and the shell membranes.

According to our findings, the single administration of the herbicide caused a significant increase in the rate of embryonic mortality and developmental abnormalities.

Some studies have labelled herbicide formulations containing glyphosate as teratogens (Dallegrave et al., 2003), but it should not be overlooked that adverse effects may vary among different animal species (Tompa, 2005; Hued et al., 2012; Mottier et al., 2013), and are affected by the duration of exposure and the dose (Várnagy and Budai, 1995).

Roongruangchai et al. (2018) studied the effect of $0.1 \mathrm{ml}$ volumes of $0.01 \%, 0.05 \%, 0.3 \%$ and $0.5 \% \mathrm{w} / \mathrm{v}$ glyphosate solution injected into the yolk sacs of eggs at $21 \mathrm{~h}$ of incubation and repeated with a volume of $0.05 \mathrm{ml}$ on day 3 of incubation. They found that glyphosate was toxic to chick embryos. It caused mortality, growth retardation and malformations on day 3 and skeletal alterations on day 6 , which also indicates its teratogenic effect.

Winnick (2013) investigated the toxic effect of glyphosate and Roundup (a glyphosate-containing product, glyphosate potassium salt, ether alkylamine ethoxylate detergent) on developing chicken embryos, when applied at a concentration of 19.8 and $9.9 \mathrm{mg}$ of active ingredient glyphosate/kg egg mass in both preparations. Survivability was significantly lower in chickens treated with Roundup than in the case of glyphosate-treated embryos. The body weight of the embryos was significantly reduced due to treatment with $9.9 \mathrm{mg} \mathrm{kg}^{-1}$ glyphosate in Roundup and $19.8 \mathrm{mg} \mathrm{kg}^{-1}$ glyphosate. A significant reduction in tibiotarsus and beak length was observed in embryos treated with Roundup (9.9 $\mathrm{mg} \mathrm{kg}^{-1}$ glyphosate). Supposedly, the high interaction potential is due to the ethoxylated detergent component, and the combined use of glyphosate and the surfactant in the same pesticide product.

Ruuskanen et al. (2020) studied the effects of a glyphosate-based herbicide applied as contaminated food on feathering and body weight gain in Japanese quails (Coturnix japonica) in order to collect more data about the effects of glyphosate-containing herbicides in avian taxa, because it is a poorly understood area. The results showed that the consumption of the contaminated food caused delayed plumage development, and residues of the herbicide were present in the eggs, muscles, and liver.

The glyphosate in Roundup induced reproductive changes (reduced levels of testosterone and oestradiol, morphological alterations of the testis and the epididymal region) in male ducks (Anas platyrhynchos) (Oliveira et al., 2007).

Basically, a pesticide product including all components was used in our study. However, other components than the active substance of the product (e.g. solvent, detergent, surfactant etc.) may have their own effect (Székács, 2017). 
Glyphosate and glyphosate-based herbicides induce a cytotoxic effect in testis and kidney cells (Vanlaeys et al., 2018; Tsatsakis et al., 2019), disturb the oestrogen pathway as endocrine disruptors (Mesnage et al., 2017), reduce testosterone production (Romano et al., 2012), and produce teratogenic malformations (Fagan et al., 2012). Furthermore, neurological alterations (e.g. anxiety, depression-like behaviours, decreased locomotor activity and learning abilities) (Ait Bali et al., 2017; Zheng et al., 2018, Ait Bali et al., 2019; Eriguchi et al., 2019), digestive problems (dysbiosis, liver fibrosis, fatty liver, altered metabolome) (Ait Bali et al., 2018; Mesnage et al., 2018; Pandey et al., 2019), cardiovascular problems (e.g. anaemia) (Wang et al., 2019), and carcinogenic effects (e. g. melanoma, leukaemia, myeloid lymphoma, myeloma (de Roos et al., 2005; Andreotti et al., 2018; Leon et al., 2019) may be produced. Glyphosate has immunotoxicological effects that affect the complement cascade, phagocytic function and the lymphocyte response and cause inflammation (Wang et al., 2019; Watanabe et al., 2019; Qiu et al., 2020).

Phenoxyethanol (POE) exerts toxic effects on human cells (hepatic, embryonic and placental cell lines), including negative effects on cellular respiration and membrane integrity, leading to necrosis and apoptosis (Mesnage et al., 2013).

Based on the scientific results, researchers stated that there is an antagonistic interaction between glyphosate and POE detergent. Although the surfactant is markedly more toxic than the glyphosate itself, their combined use can amplify or change their toxic effects (Mesnage et al., 2013, 2019; Peillex and Pelletier, 2020).

The toxic effect resulting from the interaction of a glyphosate-based herbicide and copper sulphate on chicken embryos is a quite rarely investigated topic. However, the results of combined administration in our experiment by either of the two methods showed that embryonic mortality was increased and the body weight was decreased significantly compared to the control groups.

Similarly, a glyphosate-based herbicide (Glialka Star, glyphosate potassium salt) and heavy metals (cadmium, copper) were applied alone and/or simultaneously to embryonated chicken eggs using different treatment methods to investigate their teratogenic effects. Their combined administration induced significant reduction in the body weight of the embryos and increased the rate of embryo mortality (Szemerédy et al., 2017; Szabó et al., 2020).

Due to individual and simultaneous application, developmental abnormalities (leg deformation, growth retardation, opened abdomen) were sporadically observed in our studies including both treatment methods. Our experience is in line with the scientific literature indicating that the incidence of gross developmental anomalies is sporadic and not characteristic, and abnormalities most frequently occur in the skeletal system. This is not surprising as the skeletal system has outstanding importance in experimental teratological studies (Tompa et al., 1971). However, in some cases developmental changes may also occur in the soft tissues.
Toxic interaction, at least additive action, may occur between two pesticides if they act together in the same organism at the same time. Especially if the combination contains an insecticidal component, this undesirable effect may be more severe and even synergistic by increasing toxicity up to 100 -fold. However, these effects depend on the animal species, the exposure time and the dose, and thus their routine prediction is difficult (Thompson, 1996).

\section{ACKNOWLEDGEMENT}

The publication is supported by the EFOP-3.6.3-VEKOP16-2017-00008 project (project title: Strengthening the scientific replacement by supporting the academic workshops and programs of students, developing a mentoring process). The project was co-financed by the European Union and the European Social Fund.

\section{REFERENCES}

Aaseth, J. and Norseth, T. (1986): Copper. In: Friberg, L., Nordberg, C. F. and Vouk, V. (eds) Handbook on the Toxicology of Metals. Elsevier Science Publishers, Amsterdam. pp. 529-546.

Ait Bali, Y., Ba-Mhamed, S. and Bennis, M. (2017): Behavioral and immunohistochemical study of the effects of subchronic and chronic exposure to glyphosate in mice. Front Behav. Neurosci. 11, 146.

Ait Bali, Y., Ba-M'hamed, S., Elhidar, N., Nafis, A., Soraa, N. and Bennis, M. (2018): Glyphosate-based herbicide exposure affects gut microbiota, anxiety and depression-like behaviors in mice. Neurotoxicol. Teratol. 67, 44-49.

Ait Bali, Y., Kaikai, N.-E., Ba-M'hamed, S. and Bennis, M. (2019): Learning and memory impairments associated to acetylcholinesterase inhibition and oxidative stress following glyphosate based-herbicide exposure in mice. Toxicology 415, 18-25.

Andreotti, G., Koutros, S., Hofmann, J. N., Sandler, D. P., Lubin, J. H., Lynch, C. F., Lerro, C. C., De Roos, A. J., Parks, C. G., Alavanja, M. C., Silverman, D. T. and Beane Freeman, L. E. (2018): Glyphosate use and cancer incidence in the agricultural health study. J. Natl. Cancer. Inst. 110, 509-516.

Annett, R., Habibi, H. R. and Hontela, A. (2014): Impact of glyphosate and glyphosate-based herbicides on the freshwater environment. J. Appl. Toxicol. 34, 458-479.

Blaylock, R. L. (2015): Civility in scientific publishing: the glyphosate paper. Surg. Neurol. Int. 6, 163-163.

Clegg, D. J. (1964): The hen egg in toxicity and teratogenicity studies. Fd. Cosmet. Toxicol. 2, 717-718.

Cox, C. (1995): Glyphosate, Part 2: human exposure and ecological effects. J. Pestic. Reform 15, 14-20.

Dallegrave, E., Mantese, F. D., Coelho, R. S., Pereira, J. D., Dalsenter, P. R. and Langeloh, A. (2003): The teratogenic potential of the herbicide glyphosate Roundup in Wistar rats. Toxicol. Lett. 142, 45-52. 
Danielsson, B. R. G., Oskarsson, A. and Dencker, L. (1984): Placental transfer and fetal distribution of lead in mice after treatment with dithiocarbamates. Arch. Toxicol. 55, 27-33.

Dawson, A. B. (1926): A note on the staining of the skeleton of cleared specimens with alizarin red S. Stain Techn. 1, 123-124.

de Roos, A., Blair, A., Rusiecki, J., Hoppin, J., Svec, M., Dosemeci, M., Dale, P., Sandler, D. and Alavanja, M. (2005): Cancer incidence among glyphosate-exposed pesticide applicators in the Agricultural Health Study. Environ. Health Perspect. 113, 49-54.

Duke, S. O., Lydon, J., Koskinen, W. C., Moorman, T. B., Chaney, R. L. and Hammerschmidt, R. (2012): Glyphosate effects on plant mineral nutrition, crop rhizosphere microbiota, and plant disease in glyphosate-resistant crops. J. Agric. Food Chem. 60, 10375-10397.

Eriguchi, M., Iida, K., Ikeda, S., Osoegawa, M., Nishioka, K., Hattori, N., Hiroshi Nagayama, H. and Hara, H. (2019): Parkinsonism relating to intoxication with glyphosate. Intern. Med. 58, 1935-1938.

Fagan, J., Antoniou, M., Habib, M., Howard, C., Jennings, R., Leifert, C., Nodari, R., Fagan, J. and Robinson, C. (2012): Teratogenic effects of glyphosate-based herbicides: divergence of regulatory decisions from scientific evidence. J. Environ. Anal. Toxicol. S4, 006.

Faria, M. A. (2015): Glyphosate, neurological diseases and the scientific method. Surg. Neurol. Int. 6, 132-132.

Fejes, S. (2005): Investigation of Individual and Combined Toxic Effect of Heavy Metals and Pesticides in Avian Teratology Test [in Hungarian]. Doctoral Thesis (PhD), University of Veszprém, Keszthely.

Fejes, S., Várnagy, L., Budai, P. and Takács, I. (2001): Investigation of the interaction of copper sulphate and BI 58 EC on chicken embryos [in Hungarian]. TOX'2001 Conference, Eger. Abstracts $\mathrm{C} 2-4$.

Giesy, J. P., Dobson, S. and Solomon, K. R. (2000): Ecotoxicological risk assessment for Roundup ${ }^{(B)}$ Herbicide. Rev. Environ. Contam. Toxicol. 167, 35-120.

Hejnal, M., Gottardo, D., Baldi, A., Dell'Orto, V., Cheli, F., Zaninelli, M. and Rossi, L. (2018): Review: nutritional ecology of heavy metals. Animal 12, 2156-2170.

Helander, M., Saloniemi, I. and Saikkonen, K. (2012): Glyphosate in northern ecosystems. Trends Plant Sci. 17, 569-574.

Hoffmann, D. J. and Gay, M. L. (1981): Embryotoxic effect of benzo(a)pyrene, chrysene and 7,12-dimethylbenz(a)anthracene in petroleum hydrocarbon mixtures in mallard ducks. J. Toxicol. Environ. Health 7, 775-787.

Hued, A. C., Oberhofer, S. and Bistoni, M. D. (2012): Exposure to a commercial glyphosate formulation (Roundup ${ }^{\mathbb{B}}$ ) alters normal gill and liver histology and affects male sexual activity of Jenynsia multidentata (Anablepidae, Cyprinodontiformes). Arch. Environ. Contam. Toxicol. 62, 107-117.

Institóris, L., Siroki, O. and Dési, I. (2001): Immunotoxicological investigation of combined exposure of cypermethrin, $\mathrm{Hg}^{2+}$ and $\mathrm{As}^{3+}$ on rat [in Hungarian]. TOX'2001 Conference, Eger. Abstracts $\mathrm{C} 1-2$.

Kertész, V. (2001): Effect of Heavy Metals and PAH Derivatives on Embryonic Development of Birds [in Hungarian]. Doctoral Thesis (PhD), Szent István University, Gödöllö.
Kertész, V. and Hlubik, I. (2002): Plasma ALP activity and blood PCV value changes in chick foetuses due to exposure of the egg to different xenobiotics. Environ. Pollut. 117, 323-327.

Köhler, H. R. and Triebskorn, R. (2013): Wildlife ecotoxicology of pesticides: can we track effects to the population level and beyond? Science 341, 759-765.

Komárek, M., Cadková, E., Chrastný, V., Bordas, F. and Bollinger, J. C. (2010): Contamination of vineyard soils with fungicides: a review of environmental and toxicological aspects. Environ. Int. 36, 138-151.

Korhonen, A., Hemminki, K. and Vainio, H. (1982): Embryotoxicity of industrial chemicals on the chicken embryo: thiourea derivatives. Acta Pharmacol. Toxicol. (Copenh.) 51, 38-44.

Krüger, M., Schledorn, P., Schrödl, W., Hoppe, H. W., Lutz, W. and Shehata, A. (2014): Detection of glyphosate residues in animals and humans. J. Environ. Anal. Toxicol. 4, 210.

La Torre, A., Iovino, V. and Caradonia, F. (2018): Copper in plant protection: current situation and prospects. Phytopathol. Mediterr. 57, 201-236.

Leon, M. E., Schinasi, L. H., Lebailly, P., Beane Freeman, L. E., Nordby, K.-C., Ferro, G., Monnereau, A., Brouwer, M., Tual, S., Baldi, I., Kjaerheim, K., Hofmann, J. N., Kristensen, P., Koutros, S., Straif, K., Kromhout, H. and Schüz, J. (2019): Pesticide use and risk of Non-Hodgkin lymphoid malignancies in agricultural cohorts from France, Norway and the USA: a pooled analysis from the AGRICOH consortium. Int. J. Epidemiol. 48, 519-1535.

Lipok, J., Studnik, H. and Gruyaert, S. (2010): The toxicity of Roundup $^{\circledR} 360$ SL formulation and its main constituents: glyphosate and isopropylamine towards non-target water photoautotrophs. Ecotoxicol. Environ. Saf. 73, 1681-1688.

Mahmood, I., Imadi, S. R., Shazadi, K., Gul, A. and Hakeem, K. R. (2016): Effects of pesticides on environment. In: Hakeem, K. R., Akhtar, M. S. and Abdullah, S. N. A. (eds) Plant, Soil and Microbes. Springer, Switzerland. pp. 253-269.

Mantovi, P. (2003): Rischi di accumulo del rame nei terreni. L'Informatore Agrario 59, 67-72.

Meiniel, R. (1977): Reratogenesis of axial abnormalities induced by an organic phosphorus insecticide (parathion) in the bird embryo. Wilhelm Roux's Arch. 181, 41-63.

Mesnage, R., Benbrook, C. and Antoniou, M. N. (2019): Insight into the confusion over surfactant co-formulants in glyphosatebased herbicides. Food Chem. Toxicol. 128, 137-145.

Mesnage, R., Bernay, B. and Séralini G.-E. (2013): Ethoxylated adjuvants of glyphosate-based herbicides are active principles of human cell toxicity. Toxicology 313, 122-128.

Mesnage, R., Biserni, M., Wozniak, E., Xenakis, T., Mein, C. and Antoniou, M. (2018): Comparison of transcriptome responses to glyphosate, isoxaflutole, quizalofop-p-ethyl and mesotrione in the HepaRG cell line. Toxicol. Rep. 5, 819-826.

Mesnage, R., Phedonos, A., Biserni, M., Arno, M., Balu, S., Corton, J., Ugarte, R. and Antoniou, M. (2017): Evaluation of estrogen receptor alpha activation by glyphosate-based herbicide constituents. Food Chem. Toxicol. 108(PtA), 30-42.

Mottier, A., Kientz-Bouchart, V., Serpentini, A., Lebel, J. M., Jha, A. N. and Costil, K. (2013): Effects of glyphosate-based herbicides on embryo-larval development and metamorphosis in the Pacific oyster, Crassostrea gigas. Aquat. Toxicol. 128, 67-78. 
Nielsen, L. N., Roager, H. M., Casas, M. E., Frandsen, H. L., Gosewinkel, U., Bester, K. and Bahl, M. I. (2018): Glyphosate has limited short term effects on commensal bacterial community composition in the gut environment due to sufficient aromatic amino acid levels. Environ. Pollut. 233, 364-376.

NRC (National Research Council) (1977): Copper. National Academy of Sciences, Washington. p. 115.

Ogórek, M., Gạsior, L., Pierzchała, O., Daszkiewicz, R. and Lenartowicz, M. (2017): Role of copper in the process of spermatogenesis. Postepy. Hig. Med. Dosw. (Online) 71, 663683.

Oliveira, A. G., Telles, L. F., Hess, R. A., Mahecha, G. A. B. and Oliveira, C. A. (2007): Effects of the herbicide Roundup on the epididymal region of drakes Anas platyrhynchos. Reprod. Toxicol. 23, 182-191.

Oskarsson, A. (1983): Redistribution and increased brain uptake of lead in rats after treatment with diethyldithiocarbamate. Arch. Toxicol. 6, 279-284.

Pandey, A., Dhabade, P. and Kumarasamy, A. (2019): Inflammatory effects of subacute exposure of Roundup in rat liver and adipose tissue. Dose Response 17, 1559.

Pecze, L., Papp, A. and Nagymajtényi, L. (2001): Effect of combined toxic exposure on in vivo registered hippocampal population spike [in Hungarian]. TOX'2001 Conference, Eger. Abstracts C1-4.

Peillex, C. and Pelletier, M. (2020): The impact and toxicity of glyphosate and glyphosate-based herbicides on health and immunity. J. Immunotoxicol. 17, 163-174.

Qiu, S., Fu, H., Zhou, R., Yang, Z., Bai, G. and Shi, B. (2020): Toxic effects of glyphosate on intestinal morphology, anti-oxidant capacity and barrier function in weaned piglets. Ecotoxicol. Environ. Safety 187, 109846.

Romano, M., Romano, R., Santos, L., Wisniewski, P., Campos, D., de Souza, P., Viau, P., Bernardi, M., Nunes, M. and de Oliveira, C. (2012): Glyphosate impairs male offspring reproductive development by disrupting gonadotropin expression. Arch. Toxicol. 86, 663-673.

Roongruangchai, J., Viravud, Y., Plakornkul, V., Sripaoraya, K., Vijitsombat, N. and Roongruangchai, K. (2018): The teratogenic effects of glyphosate based herbicide $(\mathrm{GBH})$ on the development of chick Embryos. Siriraj Med. J. 70, 419-428.

Ruuskanen, S., Rainio, M. J., Kuosmanen, V., Laihonen, M., Saikkonen, K., Saloniemi, I. and Helander, M. (2020): Female preference and adverse developmental effects of glyphosatebased herbicides on ecologically relevant traits in Japanese quails. Environ. Sci. Technol. 54, 1128-1135.

Solomon, K. R., Anadon, A., Carrasquilla, G., Cerdeira, A. L., Marshall, J. and Sanin, L. H. (2007): Coca and poppy eradication in Colombia: environmental and human health assessment of aerially applied glyphosate. Rev. Environ. Contam. Toxicol. 190, 43-125.

Speijers, G. J. A. and Speijers, M. H. M. (2004): Combined toxic effects of mycotoxins. Toxicol. Lett. 153, 91-98.

Szabó, R., Csonka, D., Major, L., Lehel, J. and Budai, P. (2020): Toxicity test of individual and combined toxic effects of glyphosate herbicide and heavy metals on chicken embryos. AGROFOR Internat. J. 5, 64-71.
Szemerédy, G., Szabó, R., Kormos, É., Somody, G., Somlyay, I. M., Lehel, J. and Budai, P. (2017): Toxic interaction of glyphosate and copper sulphate on chicken embryo. Comm. Agr. Appl. Biol. Sci., Ghent University, 82, 69-74.

Székács, A. (2017): Mechanism-related teratogenic, hormone modulant and other toxicological effects of veterinary and agricultural surfactants. Insights Vet. Sci. 1, 24-31.

Thompson, H. M. (1996): Interaction between pesticides; A review of reported effects and their implications for wildlife risk assessment. Ecotoxicology 5, 59-81.

Tompa, A. (2005): Chemical Safety and Toxicology. Medicina, Budapest. pp. 34-35, 43, 131.

Tompa, A., Horváth, N., Krakovits, G. and Czeizel, E. (1971): Examination of human skeleton after alizarin red staining [in Hungarian]. Morph. Ig. Orv. Szemle 11, 92-94.

Tsatsakis, A., Docea, A. O., Constantin, C., Calina, D., Zlatian, O., Nikolouzakis, T. K., Stivaktakis, P. D., Kalogeraki, A., Liesivuori, J., Tzanakakis, G. and Neagu, M. (2019): Genotoxic, cytotoxic, and cytopathological effects in rats exposed for 18 months to a mixture of 13 chemicals in doses below NOAEL levels. Toxicol. Lett. 316, 154-170.

Tullett, S. G. and Deeming, D. C. (1982): The relationship between egg shell porosity and oxygen consumption of the embryo in domestic fowl. Comp. Biochem. Physiol. 72, 529-533.

Tyler, C. (1955): Studies on egg shells. VI. The distribution of pores in egg shell. J. Sci. Food Agric. 6, 170-176.

Vanlaeys, A., Dubuisson, F., Séralini, G. and Travert, C. (2018): Formulants of glyphosate-based herbicides have more deleterious impact than glyphosate on TM4 Sertoli cells. Toxicol. In Vitro 52, 14-22.

Varga, T., Cravedi, J. P., Füzesi, I. and Várnagy, L. (2002): Residues of fenithrothion in chick embryos following exposure of fertile eggs to this organophosphorus insecticide. Rev. Med. Vet. 153, 275-278.

Várnagy, L. and Budai, P. (1995): Agrochemical Hygiene [in Hungarian]. Mezőgazda Publishing, Budapest. pp. 45, 50-52, 64-65, 70-83.

Várnagy, L., Imre, R., Fáncsi, T. and Hadházy, Á. (1981): Teratogenicity of Parathion 20 WP in Japanese quail, pheasant and chicken embryo. Acta Vet. Acad. Sci. Hung. 29, 371-321.

Várnagy, L., Molnár, E. and Budai, P. (2000): Effect of immersion fluid temperature on the chicken embryo in teratogenicity tests: short communication. Acta Vet. Hung. 48, 369-371.

Várnagy, L., Rózsa, I., Fáncsi, T. and Hadházy, Á. (1982): Teratogenicity of methylparathion $18 \mathrm{WP}$ and Wofatox $50 \mathrm{EC}$ in Japanese quail and pheasant embryos, with particular reference to osteal and muscular systems. Acta Vet. Hung. 30, 135-146.

Várnagy, L., Varga, T., Hlubik, I., Budai, P. and Molnár, E. (1996): Toxicity of the herbicides Flubalex, Fusilade $S$ and Maloran 50 WP to chicken administration as single compounds or in combination. Acta Vet. Hung. 44, 363-376.

Wang, L., Qipan, D., Hui, H., Ming, L., Zhaojian, G., Shanshan, Z. and Zijun, Y. (2019): Glyphosate induces benign monoclonal gammopathy and promotes multiple myeloma progression in mice. J. Hematol. Oncol. 12, 70.

Watanabe, Y., Tajiki-Nishino, R., Tajima, H. and Fukuyama, T. (2019): Role of estrogen receptors $\alpha$ and $\beta$ in the development 
of allergic airway inflammation in mice: a possible involvement of interleukin 33 and eosinophils. Toxicology 411, 93100.

Wilson, J. G. (1978): Review of in vitro systems with potential for use in teratogenicity screening. J. Environ. Pathol. Toxicol. 2, $149-167$.
Winnick, B. E. (2013): The Effects of Glyphosate Based Herbicides on Chick Embryo Development. MSc Thesis. University of North Texas, Texas, USA.

Zheng, Q., Yin, J., Zhu, L., Jiao, L. and Xu, Z. (2018): Reversible parkinsonism induced by acute exposure glyphosate. Parkinsonism Relat. Disord. 50, 121.

Open Access. This is an open-access article distributed under the terms of the Creative Commons Attribution 4.0 International License (https://creativecommons.org/ licenses/by/4.0/), which permits unrestricted use, distribution, and reproduction in any medium, provided the original author and source are credited, a link to the CC License is provided, and changes - if any - are indicated. (SID_1) 